\title{
Liberal Democracy and Morality: Lesbian, Gay, Bisexual and Trans-Genders (LGBTs) in Perspective
}

\author{
Edmund F Obomanu \\ Department of Political and Administrative Studies, University of Port Harcourt, Nigeria
}

\begin{abstract}
This paper examines liberal democracy and its virtues. It interrogates most of the vices in contemporary society to understand morality, which it assumes are related to unfettered freedom associated with liberal democracy. The study draws global policy attention to the place of morality in a liberal democracy and derives materials from Relational Content Analysis(RCA)as a suitable methodology to explore reasoning and principles as evidence to bring out facts and establish universal truths. The main objective is to examine the issues related to same sex marriage and by extension, the growing concern of the Lesbian, Gay, Bisexual and Transgender (LGBT) persons' rights. The result showed that unfettered rights will, in the long run, lead to moral decadence and societal decay. The paper recommends that the State should not be overbearing nor limit itself to the art of institutionalization of morality.
\end{abstract}

Keywords: Morality, Same Sex Marriage, Democracy, Sexual Right, Equality.

\section{INTRODUCTION}

Democracy, simply put, is rule by the majority or rule by the people, this depends on who we see as the majority (Mclean, 1996). Liberal democracy is a variant of democracy that places emphasis on the concept of freedom and liberty of the individuals in a political system(Macpherson,1974). In contemporary times, this form of democracy has gained so much currency that it has become the ideal and the standard for assessing good governance amongst States and the level of freedom enjoyed by citizens in a political community.

Liberal democracy has its virtues, it professes equality amongst persons, freedom of choice and particularly its emphasis on the protection and enforcement of the fundamental human rights of individuals seem to overshadow whatever credit other virtues may have. In other words, "it professes capacity to promote civil liberties by establishing the institutions and structures which guarantee and safeguard political representation" (Nna, 2004:35). The individual is seen as having natural rights which are inalienable. These rights are rights the persons are born with, given to one by his Creator and Maker. One will not be truly human if denied of such Rights and it falls under the purview of the State to protect and safeguard such rights. The individual is truly free if he or she is at liberty to choose between alternatives without interference either by other members of the political community or society or the State.

However, the interpretation, understanding or misunderstanding of the concept of liberty has stirred up a lot of controversial issues especially as it relates to issues that pertain to morality. In recent times, the moral aspect of liberal democracy have come to the front burner of political policy makers and opened up a lot of controversial issues. It has gone as far as affecting the political relationships between States in the international system. The chief protagonists in this controversy have been the Western societies championed by the United States of America and most European countries.

The morality questions stem from the values and norms of society and the fancies and choices of the individuals. While some societies have examined these issues on rights and morality through religious beliefs, traditional norms and customs that have stood the test of time, the current of change and expansion of rights have come in contrast to existing values and norms of some societies under the cloak of 'defense against the rights of the individual'. 
The problem per se rests squarely on the pressure by human rights groups and the activities of the Lesbian, Gay, Bisexual and Transgender (LGBT) movements in different political settings.

Russia has been a vocal critic of the same sex marriage. Non Western societies such as Asia, Africa and Latin America react differently to the ongoing same sex marriage debate. For instance African societies, except South Africa and a few other states, see gay relationship and marriage as immoral and unacceptable. The rationale they claim is due to the norms, values, customs and tradition. Another major point is that it is a clear departure from earlier held Christian faith, and also most traditional beliefs particularly in the African context.

The United States and most countries that make up the European Union think differently. They emphasize that it is improper to restrict individuals from choosing or expressing their feelings. To them, cultural barriers and traditional beliefs interfere with the liberty of the individual. They contend with states and societies that sanction such persons. They play down on the sovereignty of the individual States and lay claim to the protection and preservation of democratic ethos.

The controversy emanating from these are trickling down not just to the traditions, religious and cultural institutions, but also affecting the social and economic relationship. Certain States are being denied aids based on what the US terms their human rights dispositions. The United Kingdom government had cut Aid to Malawi by nineteen thousand pounds after two gay men were sentenced to 14 years with hard labor (Mitchell, 2013). In 2011, Uganda was denied 70 million pounds due to her insistence to punish homosexuality with death penalty (Dailymailonline, 2014). Some of these nonLGBT compliant States have stood their grounds. The issue is for how long they can resist the pressure from the more powerful States given their economically weak positions, especially for the economically weak states.

In this paper our concern is to explore in real terms the meaning, interpretation and understanding of what constitutes human rights especially given the issue of proliferation of rights in recent times. Secondly, we also want to examine to what extent human rights can be stretched and what are its limitations in the face of increasing demands for more rights to be recognized by States. Or are rights boundless and limitless?.

The issue is that liberal democracy has created an atmosphere of liberty and freedom. These liberties are projected through the concept of fundamental human rights. Due to the proliferation of these rights, grave moral questions have come up and some states have followed the logic and legal content of these rights at the expense of the social, moral and spiritual cost of the rights.

Our objective is to examine the extent stakeholders can protect the rights of the individual without subjecting entire societies to nauseating, and emotional stress, shame, trauma and its likes that makes the beast a lesser animal, appear more reasonable than humankind in our quest to conquer nature. Our progression starts from looking at nature, the world of the living and reproduction from plants to animals that cover the flora and fauna of the earth. This will make more meaning if we focus on the system of reproduction of species of most living things.

We assume that there is no real relationship between the liberties of individuals as it pertains to political rights and the sexual gratification of persons. The issue of what constitutes the proper choice of partners should be confined to belief systems, norms, culture and the spiritual disposition of the society since it takes more than an individual to build a social relationship. The State should limit its activities to policy making and regulative orientation; not championing sexual relationships except to check the excesses of individuals or groups.

It is also obvious, we assume, that the basic tenets of liberal democracy have been abused in the sense that most issues are dragged into democracy which has little bearing except for the fact that the State has the supreme power in every society and therefore tries to influence any area it considers of interest to its actions.

Another point is the dictatorship of liberal democracy. The liberty of individuals in the global village is now becoming the dictatorship of the politically powerful States over weak economies. There is now sanction, punishment and coercive force application which can be covertly or overtly applied on weak States who fail to accept whatever values, ideas or position of the stronger; even of such things that should be in the private domain of individuals or groups like who to go to bed with, which in most cases impede the sovereignty of the weak Societies. Democracy is fast detaching itself from rule 
of the people or majority rule to forced consent. In any case, it is apparent that liberal democracy is crashing and would fail nation-States except there is sufficient parching and cushioning to absorb the shocks of moral decadence

The issue of morality can be better understood if we examine the passions of human beings and their limitations. As Thomas Hobbes put it, man is driven by two passions viz: desires and aversion. Those things that give him pleasure he desires and sees as good and those that bring him pains or hurt he runs away from in aversion. However, it takes reason and rational thinking to make right choices because individual imagination can run wild, to the extent of thinking that they have a right to possess anything even another person's body.

The crux of the matter then, is the subject of morality and its place in liberal democracy. Morality is the soul of society. An examination of the concept of morality shows that etymologically, morality means the manner, character and proper behavior of people, it differentiates those things which society sees as good and right from the bad and wrong. The Stanford Dictionary (2011) defines it as codes of conduct put forward by a society or group and accepted by individuals for their own behavior or normatively a code of conduct that given specific conditions would be put forward by all rational persons. Despite this surface definition, its impact on the whole of society is deep and penetrating especially as it relates to the behavior, attitude and character of people in any given society.

It should be noted that generally, moral issues are those issues that concern how one ought to behave and whether a situation is proper or not. More importantly, our focus is on what should constitute the principle or basis for moral judgment noting that morality explains values that a culture holds in high standard. A lot of points can be adduced from these but let us limit ourselves to five principal principles, that will be germane to this study.

This paper argues that morality refers to the most important code of conduct put forward by a society and accepted by members of that society. While democracy provides a liberal component hinged on equality as basis of social interaction and relation, in this context a possible nexus between morality and liberal democracy would be created to provide novel theoretical causal connections and broader elucidation of the place of same sex marriage in the ongoing debate. The paper is structured as follows; the material and method, conceptual issues, morality and democracy and conclusion.

\section{MATERIALS AND MethodS}

There is obviously no singular universally acceptable mode of inquiry in the study of the subjects of democracy and morality like other social science phenomena. This study deployed the relational content analysis (RCA) to examine theoretical and conceptual issues raised on contemporary debates on democracy and morality. This is a suitable methodology as a number secondary data has discussed aspects of democracy and morality what has remained understudied are the possible causal connections linking democratic ideals with morality. Lasswell ( 1948) formulated the core questions of content analysis in its early-mid 20th-century mainstream version as it aims to understand dynamics of interactions and outcome, encompassing what individuals do and interpretations of how it is done.

Holsti (1969:14) offers a broad definition of content analysis as, "any technique for making inferences by objectively and systematically identifying specified characteristics of messages". This enables a more objective evaluation than comparing content based on the impressions. In content analysis the original source can be printed publications, broadcast programs, other recordings, the internet, or live situations. All this content is something that people have created. Content analysis is useful in quantitative and quantitative analysis (Berelson, 1952; Krippendorff, 1980; Weber, 1990; Stemler and Bebell ,1998).

In relation to the objective of this study which is to understand the core issues surrounding democracy and morality within the prism of same sex marriage legalization and human rights, this methodology provides suitable insights which would be further elucidated with the clash of civilization theoretical framework. Samuel Huntington (1997:1)argued that;

The years after the Cold War witnessed the beginnings of dramatic changes in peoples' identities and the symbols of those identities. Global politics began to be reconfigured along cultural lines. Upsidedown flags were a sign of the transition, but more and more the flags are flying high and true. 
This persistent "change in identity" is understood within the dialectics of clash between LGBTs and non LGBTs and the place of morality in a democratic system. StuartHall,etal;(1999)provide important insights on the discourse on resurgent challenges of identity in recent times, espousing its future prospects and divergent implications. In particular, Giddens(1992)reinforces the increasing challenges of sexual identity in modern societies encompassing gay, lesbian and straight with emphasis on issues of "sexual intimacy". This underscores the novel trends rooted in the liberal democracy construct.

Although dominant studies on the democratic theory is built on liberalism with predominantly three variants(Macpherson,1974) and several corresponding democratic models (Held,1972), which create seminal treatise on debates on freedom and equality and more pertinent the dynamics of the wider "liberal democratic project". Much of these have remained contestable in evolving requisite moral societal values. For instance in the context of Western modernization spreading across the globe, its morality and cultural content is discernibly interrogated as Huntington(1997:18)argues that;

Modernization has generally enhanced the material level of Civilization throughout the world. But has it also enhanced the moral and cultural dimensions of Civilization? In some respects this appears to be the case. Slavery, torture, vicious abuse of individuals, have become less and less acceptable in the contemporary world. Is this, however, simply the result of the impact of Western civilization on other cultures and hence will a moral reversion occur as Western power declines?

Similarly there are theoretical postulations on pejorative content of Western rights as basis for legalization of same sex marriage, questioning its definitive boundaries as well as the place of morality(see Resolution of the Catholic Bishops Conference,2013;Schaefer,2013).

In contemporary neo liberal order, specifically since the 2000s, there has been a rise in legalization of same sex marriage in most countries of Europe on the basis of sexual rights -The Netherlands in 2001, Belgium 2003, Spain 2005, Norway 2009, Sweden 2009, Portugal 2010, Iceland 2010, Denmark 2012; Uruguay2013, New Zealand 2013, France 2013, Scotland 2014, Luxembourg 2014, in north America Canada 2005 in Africa South Africa in 2006,in South America Argentina 2010, Brazil 2013 and USA 2015 (Amadi and Wordu,2016).

This article is concerned with the recent issues surrounding democracy and morality nexus in understanding the dialectical contentions in relation to legalization of same sex marriage.

\section{CONCEPTUAL ISSUES}

A number of conceptual issues are associated with both democracy and morality. We will pitch tent in part with Thomas Aquinas (1225 - 1274) in his work, 'Summa Theologica'. He traces the issue of natural law to reason and as he puts it, God planted knowledge of reason in all persons. Natural reason is sufficient to allow all rational persons to know what morality prohibits, requires, discourages, encourages and allows. This position is further upheld by Immanuel Kant which is central to his (Kant's) moral laws or duties as regards reason.

One of the basics of Kant on morality was to differentiate between particular and universal moral judgment which he captures in the hypothetical and categorical imperatives. Kant made ethics supreme, so real morals should be bound by law. A man's ethics usually reflects his character (Kant 1785).

The essence of morality is to be derived from the concept of law (Russell, 1961). The important point Russell raised was that everything in nature acts according to laws. The validity of this cannot be overemphasized. The fact remains that nature is guided by order, the time and seasons follow order. He further asserts that only a rational being has the power of acting according to the idea of law, that is, by the 'will'.

Gert and Gert (2016)argue that morality appears to be used in two perspectives: a descriptive perspective and a normative perspective. The descriptive sense refers to some codes of conduct advanced by a society or a group (such as a religion), or accepted by an individual for her own behavior, or normatively encompassing a code of conduct that, given specified conditions, would be deployed by all rational individuals.

In recent times, especially in liberal democratic parlance, the emphasis on the protection of the individual's right has led to a shift on the need for self-control and discipline. We know that the private good of each member of society can only be preserved if the common good of all is constantly 
kept in perspective (Ndu, 2006:2). With these as fundamental clarifications, we can now assess the relationship between the two variables of immorality and liberal democracy.

The issue is that the consequences of certain human actions are sacrificed on the altar of liberal democracy. The result is moral, spiritual and character decadence. What this portends for the future is anybody's guess. The advanced economies becloud a lot of serious issues under what they term as the protection of fundamental human rights.

Though our concern is on the human person and his or her rights and to what extent it is inalienable, unalienable and the issue of control and limitations of these rights. History has shown that the human race, especially the masses of people, have been put under one form of bondage or the other. Such bondage has taken the form of group action or community and in most cases individuals are singled out and oppressed. The experience during the monarchical rule and feudalism in Europe is informative. This to some extent opened the window for the struggle to liberate the individual and protect his natural rights.

Based on this, philosophers like John Locke and the social contract theorists have proffered ideas that will liberate the individual and as Jean J. Rousseau put it 'Man was born free but everywhere he is in chain'. For Rousseau, civil society brought this chain on human kind. These ideas have helped shape the world especially with regards to human rights issue.

Today, the United Nations have made spirited efforts in its declaration on human rights to include lots of the activities and choices of the individual as rights. These activities it has included in the declaration on human rights. Not only has the UN accepted their rights but have also tried to enforce it amongst its members. In some cases, they appear as part of the entrenched clauses in the constitution of most of the member countries.

Despite these, there has been an ever increasing demand for more rights especially by nongovernmental organization. Some of these demands appear so frivolous and even ridiculous that it seems as if the world is shifting from liberty to license. It is absurd to think of a human race where individual actions, desires and taste are boundless, limitless and frictionless freewill. It may not be obvious today but my guess is that we are already on that track. It sees existing norms and customs as objects of oppression of the minority who may be a number of base fellows. If minority is the crux of the matter does it make the action of a gang of robbers, a minority in society, right? In some cases, it looks as if the individual is boundless in his/her search for rights. Almost every action is expressed under one controversial right or the other.

A critical issue however, is the position of the government or the State in all these. Certain issues that were illegal and seen as sacrilege are now professed by most States as right of individuals without considering their cost or consequences.

\section{Discussions on Political Right Versus Morality}

Recent scholarship suggest that the human rights rhetoric has increasingly been an instrument of legalization of same sex marriage (UN,2014;Amadi and Wordu,2016).This has largely been at the heels of the June 26th 2015 supreme court ruling on legalization of same sex marriage in the United States. In the earlier days, 'rights' were focused on purely political issues given the necessities of the time particularly in $17^{\text {th }}$ century Europe. It was a right to come out of the bondage of divine authority of kings and hereditary principle. It was a right to reject the authority of the monarchy and feudal lords. It was the rise of capitalist mode of production, an incentive to give expression to free competition. Its political value was basically freedom to express political rights.

The moral angle came with the proliferation of rights and to give support to segments of society (the minority) not yet reached to improve electoral fortunes. A situation which would look like 'hey guys you know society detest you, but if you give me your votes to win elections, I will legalize your actions'. Knowing that a lot of persons in society do not show much concern on sexual frivolities until now that its weight is over-bearing on society. Most decent persons will not discuss sexual matters openly; it is this opening that the LGBTs have latched on.

The Lesbian, Gay, Bisexual and Transgender (LGBT) rights did not present much problem to society at an earlier stage. Presently, it is taken so seriously that it has become a 'must accept' for economically weak nation-states. What this means is that the US and most EU States emphasize that 
all States must allow the LGBT persons to express their right and freedom. Any state that ban or project their action as immoral will be sanctioned economically or politically or both. Gay rights are now fundamental human rights. Beyond these, there are certain questions States are yet to offer answers to especially as it concerns the LGBT rights.

The issue is this, LGBT rights outside individual sentiments, emotions and sexual comfort do not conform to nature or good reason in terms of what the functions, benefits and good that the individual will derive from these LGBT relationship. To what extent will a lesbian relationship or gay relationship sustain, promote or protect the values of society. For living organisms generally, sexual union produces not only conjugal affection but serves as main instrument for reproduction in plants and animals. It is shameful to reject these basic natural truths of life.

However, it all boils down to the core question of the pursuit of rights and the limits to which issues can be seen as rights. The freewill of all individuals will definitely lead to a collision if Thomas Hobbes' postulation in the State of nature is anything to go by. To prevent this, we will try to examine the rational individuals thought process. What prompts or promotes its choices. In this sense, we should recognize that there are negative and positive desires that spring out of the mind. It takes a disciplined mind to sieve between what is rational or not.

Where the individual fails to make rational and good choices, the state comes up to enforce such decision (Ndu, 2006). In terms of group or community behavior, it becomes difficult to impose such actions on a sovereign State. So we are left to decide on individual rights and societal values. It is our take here that the basis for accepting one over the other should be viewed in terms of benefits, function and gains over ideological issues like conforming to ethos which serves as cover under freedom to project base ideas as rights of humankind. This will lead to dire consequences of the unregulated mind in a civil society.

It is obvious that the pressure by Western societies to enforce the LGBT rights is not necessarily to set the minorities free in the non-compliant States from bondage but only to enforce the ethics or values of freedom no matter the cost. This will also not be at the cost of morality question as a number of moralists provide counter and opposing views to the idea of legalization of same sex marriage. It is also disheartening that it has now become a political and economic tool. It is ridiculous for the Western States to preach freedom of individuals to express their sexual desires on a hand and try to coerce or force politically weaker States to accept strange values irrespective of the choice of majority of the citizens in such society.

Let us examine the gay and lesbian relationship and the place of the state. An individual has instincts, drives, emotion and desires. This prompts the person to think and make decisions. These decisions may be right or wrong. It is the right of this individual to choose. On the other hand, the state, society or community, which is a collection of these individuals, try to judge what is right or wrong. The basis of this judgment in most cases is traced to the history of such people, the culture and especially religious persuasions. In every society, these issues come in diverse forms. The problem is how to locate the appropriate action and the basis of such decisions.

Early liberals of the $17^{\text {th }}$ century were more interested in peace and order like Thomas Hobbes, and for John Locke, religious toleration and liberty, freedom to self-preservation of the life, and property of individuals. He talked about limited government, non-State interference as can be exemplified in J.S. Mills' work: ON LIBERTY. They were silent on moral issues which were left within the context of culture and religion, though Mills expressed some passing reservations on morality and individual freedom.

The increase in demand of rights had led to a proliferation of rights. The quest to remain true liberals has blinded society on the nature of humankind, the vision of the future and the function of some actions. The gay person is a man who has sexual intimacy with another person of same biological sex. It is assumed that the basic gain here is sexual and emotional satisfaction. The positive product of this relationship outside its ephemeral content is debatable so one can sum it up by saying a gay or lesbian relationship is one that is done mainly to satisfy sexual urges or fancies.

This is the right of the individual, it is by choice not coercion that people enter into it, in true liberal democracy the State is not to interfere with these private matters. On the surface, this sounds good. However, our question is, that it is a human right does it make it normal, proper or good for a human? It is a human right to get what you desire, but there ought to be limits (Scruton, 2009), if one takes 
another's property it is stealing, if one takes hard drug is it not the individual's choice? Why then does the State refuse this except for the need of moderation and regulation where internal discipline fails?.

Let us examine domestic animals like cats, pigs, cows, and dogs. From their example we learn that nature abhors mating by same sex. We can even go to plants; there we find that during pollination, reproduction comes from different plants' grains. Of all reason we can adduce from nature, mating is the primary source of reproduction. The dialectics teaches us of the reconciliation of opposites for motion to occur.

We can say that nature to a large extent allows mating of opposites for the reproduction of living things after their kinds. Where these natural laws are disobeyed, there are physical and spiritual implication that worries my vision of the future.

The position of the State and different governments in contemporary times is either for or against same sex relationship. If history is anything to go by like we said earlier, facts show this in the Western societies in the early twentieth century, homosexuality and its variants were seen as mental disorder, sacrilegious and a product of debased minds. The proliferation of rights and a product of electoral votes from unassessed segments of the population, conveniently called the minority, to draw political sympathy has led to this. Governments in a bid to fulfill the electoral promises, not necessarily because the political actors are involved in this act (LGBT) by themselves, but pursue with so much force the promotion of these unnatural activities in the name of promoting individual liberties.

Certain basic issues stand to question in the course of this discourse. How will LGBT rights affect reproduction of human species?. What is the health implication of same sex relationship? What are the spiritual implications of our actions or do we swallow totally. Rene Descartes, 'I think therefore I am'. With a sense of decency and modesty, what do we tell our infants and children under sex education as regards our justification for mating one another of same biological sex? What is the true aim, goal or function of same sex relationship? Finally, what in another ten years would we count as our achievement and cost if most individuals in our societies live with persons of same sex, mate with persons of same sex and possibly abolish marriage between opposite sex?

It is a world of rights, of freedom and liberties but we should guide our choices discipline our minds and regulate our conducts.

\section{CONCluSion}

From our study, it is obvious that liberal democracy has derailed from its main objective of providing political and economic freedom. The major issues, according to the father of English liberalism John Locke (1632-1704), are self-preservation which is not in tandem with same sex relationship that on the contrary will lead to self-destruction or reduction in the process of procreation of the human race.

Locke asserts the importance of life, liberty and property as the cardinal needs of human kind and furthermore that the state should play a limited role. A situation where the Western states now use the LGBT rights as instrument of domination is more of cultural imposition than protection of rights of individuals. Socrates had argued that an unexamined life is not worth living. A critical re-appraisal of the same sex marriage beyond the rights notion is suggested.

It is safe to say that there is a relationship between proliferation of rights and moral decadence. A study of societies saddled with the moral burden of LGBT rights show that vices like sexual promiscuity, hard drug use and teenage violence are on the rise in such societies.

It is our view that personal freedom should be guided by reason. Furthermore, that the cost and benefit of state actions should be examined not only for political gains but other social, customary and health consequences. In other words, a look at History should direct our reason on what have been the gains of societies that practiced same sex marriage, sodomy and other related sexual activities.

Finally, one appreciates the resolve of those states that have been able to contain the pressure and refuse to change the norms and functional values of their society for carrots and stick. It is my suggestion that whoever considers gay marriage as normal should check the medical report of an average gay person over the last ten years.

It is difficult to believe that of all living species, it is only human beings that have turned the process of reproduction to entertainment, fun and assumed natural right. Though many may under one guise or the other confess this right but I leave them with their consequence. The question I ask is, what will society lose if LGBT rights are not legalized? 


\section{REFERENCES}

Amadi L and Wordu S(2016).The clash of sexuality or rhetoric of human rights:

Exploring same sex marriage and sustainable human development nexus International Journal of Peace and Development Studies Vol.7(1), pp. 1-14

Appadurai (2004). The Substance of Politics. London: Oxford University Press.

Berelson, B. (1952). Content Analysis in Communication Research. Glencoe, Ill: Free Press.

Catholic Bishops Statement (2013) "Human Sexuality, Marriage and Same-Sex Unions"Available at http://www.pacatholic.org/bishops-statements/human-sexuality-marriage-and-same-sexunions/\#sthash. YEuOsTU1.dpuf Retrieved 10/10/2015

Erik, E. (2012). Same Sex Marriage. Gains Cheer Gay Rights Advocates. Nov. 7, 2012. www.nytime.org.

Frisch M. et al (1997). Sexually Transmitted Infection as a Cause of Anal Cancer. www.n.engl.j.med.

Gert, B. (2005). Morality its Nature and Justification. Revised edition. New York: University Press.

Gert, B and Gert, J (2016). "The Definition of Morality", The Stanford Encyclopedia of Philosophy (Spring 2016 Edition), Edward N. Zalta (ed.), URL = <http://p lato.stanford.edu/archives/s pr2 016/entries/morality-definition/>.

Giddens, A. (1992). The Transformation of Intimacy: Sexuality, Love \& Eroticism in Modern Societies (Stanford: Stanford University Press).

Guthrie, S. Immanuel Kant and the Categorical Imperative Philosophy. Journal Vol. 11 issue 7 (retrieved Oct. 2013).

Hall S, Held D, Hubert D, Thompson K (1999). Modernity and ItsFutures. London: Polity Press/The Open University. pp.274-295.

Held, D; (1972).Models of Democracy ; Stanford University Press.

Holsti, O. (1969). Content Analysis for the Social Sciences and Humanities. Reading, MA: AddisonWesley

Huntington S, (1997)The Clash of Civilizations And the Remaking of World Order. The Reader May/June.

Kant I (1879).Freedom in Literature of Liberty Vol.2 No3 www.onlinelibrary.org retrieved12th February, 2014

Krippendorff, K. (1980). Content Analysis: An Introduction to Its Methodology. Newbury Park, CA: Sage.

Lasswell, H (1948). Power and Personality. New York, NY

Locke, J. (1690). An Essay concerning the True Original extent and End of Civil government. Peardom (ed)

Locke, J. 1988. Two Treatises of Government, ed. Laslett, P. Cambridge University Press

Macpherson C (1974).The Real World of Democracy. Clarion Press

Ndu, E. (2006). The individual, society and Discipline. The Individualism - communitarian Debate. Port Harcourt Nigeria: Amajov and Coy.

Obomanu. E. (2015). "On the unhealthy Homosexual lifestyle www.home60515.com" A Ph.D dissertation seminar presentation. University of Port Harcourt.

Schaefer, R (2013) .Sociology Matters, McGraw-Hill

Stemler, S and Bebell, D. (1998). An Empirical Approach to Understanding and Analyzing the Mission Statements of Selected Educational Institutions. Paper presented at the annual meeting of the New England Educational Research Organization. Portsmouth, New Hampshire. Available: ERIC Doc No. ED 442202.

Weber, R. (1990). Basic Content Analysis, 2nd ed. Newbury Park, CA.

\section{AUTHOR'S BIOGRAPHY}

Edmund F Obomanu, Holds a Phd in Political Theory and Lectures in the Department of Political Science and Administrative Studies, University of Port Harcourt, Nigeria .He Has Several Publications in Learned Journals. 